\title{
Accounting
}

homepage: www.GrowingScience.com/ac/ac.html

\section{Board mechanisms and corporate market value: Panel Data Evidence from Jordan}

\author{
Fawzi A. Al Sawalqa ${ }^{a^{*}}$
}

${ }^{a}$ Accounting Department, Business Faculty, Tafila Technical University, Tafila, Jordan

\begin{tabular}{l}
\hline C H R O N I C L E \\
\hline Article history: \\
Received: October 27, 2020 \\
Received in revised format: \\
November 26 2020 \\
Accepted: December 9, 2020 \\
Available online: \\
December 9, 2020 \\
\hline Keywords: \\
Board mechanisms \\
Market value \\
Tobin's $Q$ \\
Board size \\
Audit committee meetings \\
Random Effect Model \\
\hline
\end{tabular}

\section{A B S T R A C T}

\begin{abstract}
The study examines the effect of board size, frequency of board meetings and frequency of audit committee meetings on the market value of 11 Jordanian commercial banks as measured by Tobin's Q. Random effect panel data regression is employed to test the study hypotheses. Results reveal that board size has a significant and negative effect on bank market value. Results also show that frequency of board meetings has no effect on bank value, while the frequency of audit committee meetings has a significant and positive effect on bank value. The results suggest that the argument of agency theory and resource independence theory towards the role of board and its committees in supporting firm value should be always combined with the appropriate size. Accordingly, one important implication of the study is that the selection of an appropriate number of board members and the prior effective preparation for their meetings are critical factors to enhance the value of banks in Jordan.
\end{abstract}

\section{Introduction}

The international 2007-2008 financial crisis has significantly affected the financial firms in all over the world and reinforced the role of corporate governance as a critical control (Erkens, Hung \& Matos, 2012) and risk management instrument in such firms (Aebi, VSabato \& Schmid, 2012). Therefore, the corporate governance mechanisms become dominants in measuring the development of the economy and nations (Bista et al., 2019). The Basel Committee on Banking Supervision (BCBS) has considered the corporate governance system as a vital tool to improve the banking system and the economic system as a whole and has encouraged banks to control their daily work and to monitor the behavior of managers through the different corporate governance mechanisms (de Andres \& Vallelado, 2008). However, one of the critical roles of a good governance system is to create a balance between managers and owners in order to decrease the agency cost and to direct the efforts of managers toward the benefit of shareholders (Jiraporn, Kim \& Kim, 2011).

A good governance system can protect the rights of shareholders through creating the necessary committees to monitor the different aspects of managers' decisions and to ensure the application of all the necessary rules that can govern the different aspects of firms' activities (Sidhu \& Kaur, 2019). The strength of governance is an important indicator about the ability of firm to use the accessible resources in an effective way to compete in the current business market (Gregory \& Simms, 1999). According to de Andres et al. (2012) prior studies in banking governance have suggested that board size, composition and responsibilities have contributed significantly toward establishing and deepening the values and rules of corporate governance. Moreover, it is well known that the corporate governance system in banking sector is unique and different from that of other sectors due to multiplicity of their stakeholders such as depositors, borrowers, shareholders and employees (Adams \& Mehran, 2003; Crespí, García-Cestona \& Salas, 2004; Bushman, 2014). Therefore, the current study focuses mainly on the different attributes of board of directors as

* Corresponding author. Tel: $962-772282190$

E-mail address: fsawalqah@tttu.edu.jo (F. A. Al Sawalqa) 
they play critical role in the different activities and decisions of banks (Adams \& Mehran, 2003). In particular, the study investigates the effect of board size, frequency of board meetings and frequency of audit committee meetings on the market value of 11 Jordanian commercial banks as measured by Tobin's Q for the period from 2013 to 2019.

The current study is different from prior studies in corporate governance field in several issues. First, the study contributes to the current knowledge in the field as it offers a new reference (2013-2019) in the relationship between board mechanisms and the market value of banks in emerging markets such as Jordan. Second, unlike prior studies, the current study focuses mainly on banking sector due to its unique features in comparison with other sectors. Third, the study employs efficient panel regression technique to empirically test the relationship between the dependent and independent variables. Fourth, the study has proved the importance of controlling for the investment opportunity in the relationship between board mechanisms and Tobin's Q. Finally, the study has determined the importance of identifying an appropriate size for directors in firms to effectively support firm value.

\section{Central Bank of Jordan and the Amended Instructions of Corporate Governance}

It can be argued that corporate governance is more deeply rooted in the banking sector in Jordan compared to other sectors. This is due to the efforts of Central Bank of Jordan (CBJ) and its different control tools in inspiring banks to comply with the main principles of corporate governance. This, however, is obvious as such banks have started early to prepare the corporate governance reports as a part of their annual reports. The CBJ issued the Amended Instructions of Corporate Governance for Banks No.63/2016 which is considered an important shift in the work of banks in Jordan (CBJ, 2016a). Article (4) of the Amended Instructions of Corporate Governance for Banks No.63/2016 gives the banks the general framework to build their own corporate governance code, whereas article (5) asks the banks to publish such codes on their own websites and to prepare an integrated governance report enclosed within the annual reports (CBJ, 2016a, p.4). The amended instructions have also focused on the different attributes of corporate governance. Since the current study focuses on the effect of board mechanisms on the bank market value, the study in this section puts more emphasis on the different mechanisms as outlined in such amended instructions.

Article (6) of the amended instructions focuses on the board of directors composition in that paragraph (A) identifies the minimum size of board of directors at 11 members, paragraph (B) prevents any member of board of directors to be executive, while paragraph (C) identifies the minimum number of independent members at 4, and paragraph (D) outlines the minimum requirements for independency (CBJ, 2016a, p.5). Article (7) in its paragraphs (A, B, and C) focuses on the necessary rules for meetings of the board of directors, while article (8) outlines in some details the main responsibilities of board of directors and the main duties of the board secretary (CBJ, 2016a, p. 5-10). Most important, paragraph (E) of article (9) prevents delegating the powers of chairman and general manager to one person and that the general manager must be full independent from others (CBJ, 2016a, p.11). Article (10) focuses on the different issues of board committees with some emphasis on audit committee in paragraph (B), while other articles focus on the necessary principles that deal with control, risk, audit, shareholders, and transparency and disclosure (CBJ, 2016a).

The banking system in Jordan is very robust and is subject to a consistent set of legislations. In addition, Jordanian banks adhere to the international banking system and to international standards in accounting and auditing.

\section{Literature Review and Hypotheses Development}

\subsection{Theoretical Framework}

The conflict between the owners and managers and the different consequences of such conflict are all discussed through several theories. One important theory that is taken a considerable emphasis by several scholars is agency theory which focuses mainly on the conflict of interests between managers and shareholders (Hill \& Jones, 1992). Early, Jensen and Mecklng (1976) outlined the main idea of agency theory in that it deals with the conflict between the shareholders and the business managers, which is reflected in agency costs resulted from imposing several managerial systems including, for example, monitoring, incentives and compensation systems due to the efforts of board of directors and owners to ensure that the managers' decisions are in favor of the owners. That is, as both the managers and owners try to gain more benefits at low cost (Davis, Schoorman \& Donaldson, 1997), the idea of separation of management and ownership has been taken place (e.g. Fama, 1980; Fama \& Jensen, 1983) and consequently the ideas of monitoring the behavior of business managers and reducing the agency problem have also taken place (e.g. Davis et al., 1997; Hillman \& Dalziel, 2003; Lan \& Heracleous, 2010). However, the notion of agency theory and the behavior of owners to protect their benefits at the presence of the ongoing conflict between the different parties in the firm and the potential consequences on the firm value are also discussed recently by several researchers (e.g. Antenucci, 2019). In addition, prior studies examined empirically the theoretical bases of agency theory with some emphasis on the different mechanisms of corporate governance and their potential impact on the different perspectives of firm value. Examples include board characteristics in Bhat et al. (2018); Asante-Darko et al. (2018); Agyemang-Mintahand and Schadewitz (2019), committees in Mazzotta and Veltri (2014); Farhan, Obaid and Azlan (2017); Pahi and Yadav (2019) and Sidhu and Kaur (2019), independency in Ibrahim, Ahmad and Khan (2017) and ownership structure in Mishra and Kapil (2017). 
In addition to agency theory, there are some other theories that predict the impact of various governance tools on the value of firms. Examples include stewardship theory, which contradicts agency theory in its view to managers behavior and considers the management objectives are fully in line with those of shareholders in that the steward always tries to give more attention to the cooperation with principal and seeks to achieve the objectives of the organization by maximizing both the performance of it and the wealth of shareholders (Davis et al, 1997). According to steward theory the role of corporate governance mechanisms here is to "facilitate and empower rather than those that monitor and control" (Davis et al., 1997, p. 26).

Another important theory is resource dependence theory which is built on the notion that any firm is affected by the external factors and the management role is to mitigate such influence by reducing the uncertainty (Hillman, Withers \& Collins, 2009). Therefore, the role of corporate governance is very vital in using the resources of the firm to attract the necessary low cost capital to the firm and to protect its assets by monitoring the ability of managers in using such resources to generate income (Gregory \& Simms, 1999). The responsibility lies primarily on the board of directors in attracting the appropriate investments for the firm (Hillman, Withers \& Collins, 2009) as they have the necessary technical experience and relations to fully carry out their duties (Hillman \& Dalziel, 2003). In addition, the stakeholder theory focuses on maximizing the wealth of all the related parties in firm (Agyemang-Mintahand \& Schadewitz, 2019).

However, most of corporate governance theories are interrelated and therefore several prior studies in the field are based on one theory or more in studying the consequences of employing the different corporate governance attributes. Examples of such studies include using agency, stakeholder and resource dependence theories by Agyemang-Mintahand and Schadewitz (2019), using agency and resource dependence in Hillman and Dalziel (2003), using agency, stakeholder and stewardship theories in Van Puyvelde et al. (2012). Therefore, the current study follows the prior studies in the field with some emphasis on agency theory.

\subsection{Literature Review}

This section reviews the empirical studies that tied the different mechanisms of corporate governance with the corporate value at different contexts and proposes the main hypotheses for the current study. Prior studies that have focused on the relationship between corporate governance and firm value have measured the quality of corporate governance through a broad set of internal variables. This indicates that there is no concurrence, even if almost roughly, on the use of specific set of corporate governance attributes to measure their impact on firm value. For example, an insight into some recent studies clearly justifies this argument in several studies (e.g. Eberhart, 2012; Kusi et al., 2018; Schäuble, 2019) that have used wide and sometimes heterogeneous mixture of mechanisms to measure the quality of governance and thus to determine its impact on firm value. Others focused on small and homogeneous group of corporate governance mechanisms but used several controlling variables. Examples including using board size, board independence, and board meetings in Bhat et al. (2018), board diversity in Agyemang-Mintahand and Schadewitz (2019), and ownership structure in Mishra and Kapil (2017). In respect to the firm value, a wide range of market and accounting variables were used to measure it. Several studies (e.g. Asante-Darko et al., 2018; Bhat et al., 2018; AgyemangMintahand \& Schadewitz, 2019; Kong et al., 2020) have used only Tobin's Q, which represents the market value of firm. Others (e.g. Farhan et al., 2017; Mishra \& Kapil, 2018) used both Tobin's Q and accounting measures such as ROI and ROA. However, corporate governance studies were not limited to such types of relationships. Other studies, for examples, investigated the relationship between the corporate governance mechanisms and dividends policy in Elmagrhi et al. (2017) and Pahi and Yadav (2019), shareholders value in Ibrahim et al. (2017) and Kusi et al. (2018), stock price in Malik and Shah (2013), equity capital cost in Mazzotta and Veltri (2014), agency cost in Schäuble (2019), stock market liquidity in Sidhu and Kaur (2019).

Empirical studies that have focused on firm value impact of corporate governance using only Tobin's $Q$ as a firm market value measure revealed mixed results. Early, Del Brio, Maia-Ramires and Perote (2006) findings indicated that the value of firms is better at small size firms with a favorable audit report, high compensation and more directors' remuneration. Eberhart (2012) results indicated that using the new corporate governance system which depends on the presence of committees contributed significantly in the value of Japanese firms during the period from 1999 to 2008. Rashid and Islam (2013) findings revealed that board size has a positive and significant effect on the value of Malaysian listed firm for the period from 2000 to 2003, while the effect of concentrated shareholders was negative and significant. Bhat et al (2018) findings indicated that both board size and board meetings have no effect on the value of Pakistani firms for the period from 2010-2014, while the effect of board independence was positive and significant. Asante-Darko et al (2018) findings also indicated that both board size and nonexecutive directors on the board have no effect on the value of Ghanaian companies during the period from 2010 to 2014. Recently, Agyemang-Mintahand and Schadewitz (2019) found that the existence of female at the board team is positively and significantly affected the value of the UK financial firms especially prior to the financial crisis.

Similarly, the findings of studies that used Tobin's Q to measure the firm value in addition to other accounting and market measures were also shown mixed results. Early, Haniffa and Hudaib (2006) performed a study to show the effect of corporate governance mechanisms on the value of Malaysian listed companies for the period from 1996 to 2000 as measured by both Tobin's Q and ROA. Authors results revealed that board size, multiple directorship and top shareholders affected Tobin's Q negatively and significantly, while both proportion of non-executive directors on the board and the role duality have no effect on the Tobin's Q. Ntim and Osei (2011) investigated the effect of the frequency of board meetings on the performance of South African listed companies for the period from 2002 to 2007. The performance was measured using Tobin's Q, ROA and Total Shareholders 
Return (TSR). Authors findings revealed a positive and significant relationship between the frequency of meeting and the firm performance as measured by Tobin's Q. Farhan et al (2017) findings show that the effect of audit committee incentives and audit committee independence on Tobin's Q was negative and significant, while the board independence, board size, financial experts and audit committee meetings have not affected on Tobin's Q, and both the board independence and foreign ownership have affected the ROA of UAE negatively and significantly during the period from 2010 to 2013. Mishra and Kapil (2017) performed a study to investigate the effect of ownership structure and board mechanisms on the performance of Indian listed companies for the period from March 312010 to March 312014 as measured by Tobin's Q and ROA. Authors' findings indicated that institutional ownership and foreign institutional ownership were positively affected Tobin's Q but not ROA, while the board size was positively affected ROA. Mishra and Kapil (2018) also performed a study to investigate the effect of some board characteristics on the performance of Indian listed companies as measured by Tobin's Q and ROA for the period from 2010 to 2014. Authors findings indicated that board independence was positively and significantly affected ROA but not Tobin's Q, while board meetings was positively and significantly affected Tobin's Q and CEO duality and board size were significantly affected both of the performance measures.

In context of Jordan, Al-Khouri (2006) investigated the relationship between the ownership structure and firm value as measured by Tobin's Q at industrial and service listed companies. Other Jordanian studies focused on several other topics in this field. Examples include the impact on dividends policy at banks in Daradkah and Ajlouni. (2013), at industrial listed companies in AlAmarneh and Yaseen (2014), at all listed companies in Alkurdi, Tahat and Al-mawali (2017), at the listed industrial and services companies in Al-Rahahleh (2017). Examples in Jordan also include the impact on earnings management at the listed industrial and services companies in Abbadi et al. (2016) and at the financial listed companies in Azzoz and Khamees (2016). In addition, the effect on disclosure at the commercial banks in Al Attar (2016), at service and industrial listed companies in Albitar (2015) and Al Fadli et al. (2019), and at all listed companies in Al-Nimer (2019). In addition, some studies investigated the effect of corporate governance attributes on performance at financial listed companies as Hamdan, Sarea, and Reyad (2013) and Bawaneh (2020) and at service and industrial listed companies in Alabdullah, Yahya and Ramayah (2014). Examples also include the relationship between corporate governance and working capital management at the listed manufacturing companies in Abu Khalaf and Al-Tarawneh (2019).

In general, it has been noted that previous studies in Jordan ignored the banking sector and some of such studies included the banking sector with insurance sector under financial sector despite that each sector has its own corporate governance code. Accordingly, the current study focused mainly on the banking sector in Jordan to overcome the limitations in prior research and to add new addition to the knowledge in the field.

\subsection{Hypotheses Development}

\subsubsection{Board Size and Firm Value}

According to the agency theory, the presence of board of directors is very vital to shareholders as they can monitor the ongoing decisions of management and protect their rights in the firm which contributes significantly toward the firm value (Hillman \& Dalziel, 2003). In addition, the resource independence theory also gives more emphasis to the role of active board in attracting resources to the firm in low cost (Hillman \& Dalziel, 2003; Hillman, Withers \& Collins, 2009). Stewardship theory also views that large boards are vital to firm and enrich decisions (Rashid \& Islam, 2013). This, however, is possible when the size of directors is optimal to coordinate their efforts mutually to the favor of firm in every circumstance without any delay (Rashid \& Islam, 2013). In this context, Jensen (1993) argued that board of directors can contribute toward the firm value only when their size is small and not exceeds seven or eight members. Similarly, Lipton and Lorsch (1992, p. 65) criticized the large number of director and stated that "When a board has more than ten members, it becomes more difficult for them all to express their ideas and opinions in the limited time available". In addition, Lipton and Lorsch (1992) were also with the reducing of the size of board of directors to eight or nine. In this context, the Amended Instructions of Corporate Governance for Banks No.63/2016 identify the minimum size of board of directors at 11 members (CBJ, 2016a). Therefore, the minimum size of board of directors in Jordanian banks exceeds that suggested by Lipton and Lorsch (1992) and Jensen (1993). Empirically, findings of prior studies that investigated the effect of board size on firm value as measured by Tobin's Q revealed mixed results. For example, prior research that conducted in emerging markets (e.g. Farhan et al., 2017; Bhat et al., 2018; Asante-Darko et al., 2018) found no relationship between board size and firm value, while some studies (Rashid \& Islam, 2013; Naseem et al., 2017; Mishra \& Kapil., 2018) found a positive and significant relationship. Other studies (Haniffa \& Hudaib, 2006; Kumar \& Singh, 2013) found a negative relationship. In line with the arguments of prior research (e.g. Lipton \& Lorsch, 1992; Jensen, 1993) in respect to the expected diverse effect of large number of board of directors on firm value, it can be hypothesized that:

$\mathrm{H}_{1}$. There is a significant negative relationship between board size and corporate market value.

\subsubsection{Frequency of board meetings and firm value}

It has been argued that agency theory believes that frequency of board meetings enhances firm value as it keeps the activities of management under the control of boards (Ntim \& Osei, 2011), which in turn forces the management to work to the favor of shareholders (Bhat et al., 2018). In this context, Jensen (1993) argues that the frequency of meetings is very important as it 
coordinates the plans and gives the opportunity for the different managerial levels to understand their desires and activities in the company. Another argument focuses on the role of meetings in bearing additional expenses without any impact on firm value due to the limited time of such meetings (Bhat et al., 2018). The Amended Instructions of Corporate Governance for Banks No.63/2016 have not outlined the minimum number of board of directors meetings. However, paragraph (D) of Article 11 of Instructions of Corporate Governance for Shareholding Listed Companies for the year 2017 determines the minimum number of meetings at six yearly (JSC, 2017). In general, it has been noted that most of prior studies avoided including the frequency of meetings in their investigation due to the missing data problem (Mishra \& Kapil, 2018). However, most of the available prior studies found mixed results in respect to the relationship between frequency of board meetings and firm value as measured by Tobin's Q. For example, prior research (Ntim \& Osei, 2011; Mishra \& Kapil, 2018) found a positive and significant relationship between frequency of board meetings and firm value. Other studies (e.g. Naseem et al., 2017; Bhat et al., 2018) found no relationship between frequency of board meetings and corporate market value. Consequently, it can be hypothesized that:

\section{$\mathrm{H}_{2}$. There is a significant positive relationship between the frequency of board meetings and corporate market value.}

\subsubsection{Frequency of audit committee meetings and firm value}

According to Gregory and Simms (1999), the audit committee plays a significant role in keeping the rights of shareholders and other related parties in any firm. Therefore, the Amended Instructions of Corporate Governance for Banks No.63/2016 give more attention to the audit committee in Article 10. These instructions have not identified the minimum number of audit committee meetings, while paragraph (G) of Article (6) of the Instructions of Corporate Governance for Shareholding Listed Companies for the year 2017 determines the minimum number of meetings at four yearly (JSC, 2017). In addition, paragraph (B) of Article 10 of the Amended Instructions of Corporate Governance for Banks No.63/2016 determines the composition, practical experiences, and the duties of audit committee members (CBJ, 2016a).

However, it has been argued that the presence of audit committee decreases the agency problem (Bhat et al, 2018), which in turn enhances the quality of financial reporting in the firm (Farhan et al., 2017). Empirically, the results of previous studies were also mixed. For example, Farhan et a.1 (2017) found no relationship between the frequency of audit committee meetings and firm value. On the other hand, Sidhu and Kaur (2019) found a negative and significant relationship between the frequency of audit committee meetings and the liquidity of market. Accordingly, it can be hypothesized that:

$\mathrm{H}_{3}$. There is a significant positive relationship between the frequency of audit committee meetings and corporate market value.

\section{Methodology}

\subsection{Sample and Data}

The current study focuses on the Jordanian banking sector during the period from 2013 to 2019. Jordan has 16 listed banks. The sample of the study consists of 11 banks, which gives a total of 77 observations. As shown in Table 1, three Islamic banks were excluded due to their own legislative system and are also covered by their own governance instructions which were issued by CBJ in 2016 under the title "Amended Instructions of Corporate Governance for Islamic (Sharia Compliant) Banks No. (64/2016) dated 25/9/2016 (CBJ, 2016b). In addition, 2 other banks were excluded due to the missing of governance data. Previous studies suffer from a shortage in those studies that focus mainly on the banking sector. Accordingly, the current study is an important addition to the knowledge in this field and also focuses on a very recent period.

The data were mainly taken from the annual corporate reports of Jordanian banks that listed at Amman Stock Exchange (ASE), where the audited financial statements and the corporate governance reports are included. In addition, the market data were taken from Securities Depository Center (SDC) website in order to compute the dependent variable (Tobin's Q ratio). The control variable data (investment opportunity) were also taken from SDC website.

\section{Table 1}

The study sample

\begin{tabular}{llll}
\hline Population & & Number & $\%$ \\
\hline Total & 16 & 100 & \\
Less: & $(3)$ & & \\
Islamic banks & $(2)$ & $(18.75)$ & \\
Missing governance data & 11 & $(68.75)$ \\
\hline Final Sample & & \\
\hline
\end{tabular}

\subsection{Measurement of Variables}

1. The dependent variable Tobin's Q ratio (TQ): It is known that corporate value can be measured through accounting measures such as ROA and market measures such as Tobin's Q and market to book value (MBV) (e.g. Berthelot et al., 2012; Siddiqui, 2015; Mishra \& Kapil, 2018). According to Siddiqui (2015), Tobin's Q is a market measure reveals both the long-term corporate value and the weight of corporate governance mechanisms. Therefore, several prior studies (e.g. Del Brio et al., 2006; Eberhart, 2012; 
Rashid \& Islam, 2013; Bhat et al., 2018; Asante-Darko et al., 2018; Agyemang-Mintahand \& Schadewitz, 2019) that tested the effect of corporate governance mechanisms on the firm value used only Tobin's Q to measure the corporate value. However, several methods were used to compute Tobin's Q (Perfect \& Wiles, 1994). Tobin's Q ratio can be computed as the market value of equity plus book value of debt divided by the book value of total assets (e.g. Del Brio et al., 2006; Farhan et al., 2017; Mishra \& Kapil, 2018).

2. The independent variables: the current study focuses on the board mechanisms to measure the effectiveness of corporate governance in banks. The independent variables are bored size, frequency of board meetings and the frequency of audit committee meetings. The board size (BSIZ) represents the total number of directors on the board and is used in most prior studies that interested in the current topic (e.g. Haniffa \& Hudaib (2006; Farhan et al., 2017; Bhat et al., 2018; Asante-Darko et al., 2018; Rashid \& Islam, 2013; Elmagrh et al., 2017; Naseem et al., 2017; Mishra \& Kapil., 2018). The frequency of board meetings (BMET) represents the number of meetings held by board during the year (e.g. Ntim \& Osei, 2011; Mishra \& Kapil, 2018; Naseem et al., 2017; Bhat et al., 2018). Finally, the frequency of audit committee meetings (AMET) represents the number of meetings held by audit committee during the year (Farhan et al., 2017; Sidhu \& Kaur, 2019).

3. The controlling variable investment opportunity (INVOP): due to the nature of the current study which focuses on examining the effect of board mechanisms on the market value of banks, it can be argued that the presence of investment opportunity as a control variable is very appropriate due to its close relationship with Tobin's Q as suggested in prior studies (Blundell et al., 1992; Eberhart, 2012). INVOP is measured as market value per share divided by book value per share (Dewasiri et al., 2019).

\subsection{Panel Regression Model}

The model of study represents the empirical relationship between the different variables as shown below:

$$
\text { Tobin's } Q=\alpha+\beta_{1} B S I Z_{i t}+\beta_{2} B M E T_{i t}+\beta_{3} A M E T_{i t}+\beta_{4} I N V O P_{i t}+\varepsilon_{i t}
$$

Each of the components of the study model is defined as shown in Table 2.

Table 2

Measurement of variables

\begin{tabular}{|c|c|c|c|}
\hline Variable & Symbol & Measurement & Refernce \\
\hline \multicolumn{4}{|l|}{ Dependent variable: } \\
\hline Firm value Tobin's Q & TQ & $\begin{array}{l}\text { Market value of equity }+ \\
\text { book value of } \\
\text { liabilities/Total assets }\end{array}$ & $\begin{array}{l}\text { Del Brio et al. (2006); Kumar and Singh (2013) Farhan et al. 2017; Mishra and } \\
\text { Kapil (2018). }\end{array}$ \\
\hline \multicolumn{4}{|l|}{ Independent variables: } \\
\hline Board Size & BSIZ & $\begin{array}{l}\text { The number of the board } \\
\text { members }\end{array}$ & $\begin{array}{l}\text { Haniffa and Hudaib (2006); Rashid and Islam (2013); Farhan et al. (2017); } \\
\text { Elmagrh et al. (2017); Naseem et al. (2017); Bhat et al. (2018); Asante-Darko et } \\
\text { al. (2018); Mishra and Kapil (2018). }\end{array}$ \\
\hline Board Meetings & BMET & $\begin{array}{l}\text { Number of board } \\
\text { meetings held during the } \\
\text { year }\end{array}$ & $\begin{array}{l}\text { Ntim and Osei (2011); Naseem et al. (2017); Mishra and Kapil (2018); Bhat et al. } \\
\text { (2018). }\end{array}$ \\
\hline Audit committee meetings & AMET & $\begin{array}{l}\text { Number of audit } \\
\text { committee meetings held } \\
\text { during the year }\end{array}$ & Farhan et al. (2017); Sidhu and Kaur (2019). \\
\hline \multicolumn{4}{|l|}{ Control variable: } \\
\hline Investment Opportunity & INVOP & $\begin{array}{l}\mathrm{MBV}=\text { market value per } \\
\text { share/book value per } \\
\text { share }\end{array}$ & Dewasiri et al. (2019) \\
\hline
\end{tabular}

\section{Results and Discussion}

\subsection{Descriptive statistics and Correlation analysis}

Table 3 shows the descriptive statistics for the dependent, independent and control variables of the study for the period from 2013 to 2019. The ratio of Tobin's Q ranged from 0.904 to 1.1875 which is less dispread than those of other studies (Farhan et al., 2017; Mishra \& Kapil, 2018). The mean value is almost equal one (0.9926). This mean value is less than that of Rashid and Islam, (2013); Farhan et al. (2017); Asante-Darko et al. (2018); Bhat et al. (2018); Mishra and Kapil, (2018).

The average board size is about 11.3766. This complies with the Amended Instructions of Corporate Governance for Banks No.63/2016 which identified the minimum size of board of directors at 11. Consistent with the findings of Ntim and Osei (2011) and Sidhu and Kaur (2019), the board meetings are ranged from 6 to 19 meetings, with an average of 8.2207 meetings. The audit committee meetings are ranging from 0 to 21 times yearly, with an average of 7.6883. This result is larger than that of Farhan et al. (2017). In general, these results reveal that banks in Jordan comply with the Amended Instructions of Corporate Governance for Banks No.63/2016 to a considerable extent. 
Table 3

Descriptive statistics

\begin{tabular}{|c|c|c|c|c|}
\hline Variable & Mean & SD & Minimum & Maximum \\
\hline \multicolumn{5}{|c|}{ Dependent Variable: } \\
\hline Tobin's Q & 0.9926 & .061235 & 0.904 & 1.1875 \\
\hline \multicolumn{5}{|c|}{ Independent Variables: } \\
\hline BSIZ & 11.3766 & 1.40524 & 7.00 & 13.00 \\
\hline BMET & 8.2207 & 2.71750 & 6.00 & 19.00 \\
\hline AMET & 7.6883 & 3.82945 & 0.00 & 21.00 \\
\hline \multicolumn{5}{|c|}{ Control Variable: } \\
\hline INVOP & 0.9441 & 0.44399 & 0.452 & 2.441 \\
\hline
\end{tabular}

Table 4 shows that all the correlation coefficients are low enough to indicate that the problem of multicollinearity is not of concern. This is also consistent with the results that outlined in Table 5, where the values of variance inflation factor (VIF) are in the relevant range.

Table 4

Correlation Matrix

\begin{tabular}{cccccc}
\hline & TQ & BS & BM & AMET & \\
\hline TQ & 1 & & & & \\
BSIZ & 0.1779 & 1 & & \\
BMET & -0.0666 & -0.1702 & 1 & 1 & -0.2119 \\
AMET & -0.2055 & 0.2837 & 0.3519 & -0.0845 & 1 \\
INVOP & 0.9928 & 0.1997 & & \\
\hline
\end{tabular}

Table 5

Variance Inflation Factors (VIF) test results

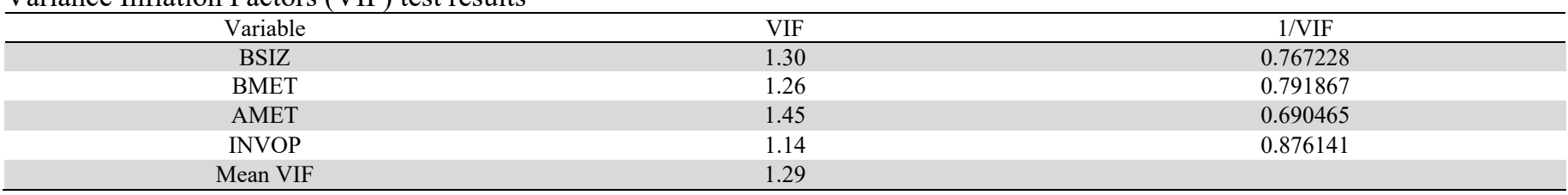

\subsection{Panel Data Analysis}

According to Gujarati and Porter (2009) the panel data regression has the ability to combine "time series and cross-section data", examine the interrelated relations and mitigate the specification errors of regressions. Accordingly, the current study employs the panel data regression by following a systematic approach to select the appropriate model.

\subsubsection{Fixed effect model versus Random effect model}

To test the effect of the independent variables on the dependent variable, the pooled OLS regression was firstly performed using STATA version 15. Then, the fixed effect model (FEM) was performed. In the third stage, the random effect model (REM) was performed. According to Gujarati and Porter (2009), two tests are used to select the appropriate model. These include:

1. The Hausman test to decide between FEM and REM.

2. The Breusch and Pagan Lagrange Multiplier test to decide if REM is appropriate.

Accordingly, the Hausman test is firstly performed. Table 6 shows the Chi square statistics. As shown, the probability is insignificant $(\mathrm{p}=0.2903>0.05)$. Accordingly, the null hypothesis which stated that REM is appropriate is accepted. Therefore, until this step the REM is the relevant model to perform the panel regression.

Table 6

Hausman test results

\begin{tabular}{lcc}
\hline Hausman Test & Chi-Square Statistic & probability \\
\hline Results & 4.97 & 0.2903 \\
\hline
\end{tabular}

To decide if REM is the appropriate model against the Pooled OLS, the Breusch and Pagan Lagrange Multiplier test for random effects is performed. As shown in Table 7, the probability of Chi square is significant $(\mathrm{p}=0.0000<0.05)$. Accordingly, the null hypothesis which stated that pooled OLS regression is appropriate is rejected and the alternative hypothesis which stated that REM is appropriate is accepted. Therefore, the REM is the most appropriate to examine the effect of BSIZ, BMET, AMET and INVOP on Tobin's $Q$. 
Table 7

Breusch and Pagan Lagrange Multiplier test for random effects

\begin{tabular}{lrr}
\hline Breusch and Pagan LM test for random effects & Chi-Square Statistic & probability \\
\hline Results & 66.16 & 0.0000 \\
\hline
\end{tabular}

It is important to check if the REM has serial correlation. Pesaran CD test is performed to check if the model has serial correlation. As shown in Table 8, the result of Peseran test indicates that the model has not any serial correlation $(p=0.5553)$.

Table 8

Pesaran CD test results

\begin{tabular}{lll}
\hline Pesaran CD test & Pesaran's test of cross sectional independence & Probability \\
\hline Results & 0.590 & 0.5553 \\
\hline
\end{tabular}

Based on the above diagnoses' procedures, it can be argued that the REM is the appropriate model to go further in testing the study hypothesis.

\subsubsection{Random Effect Model Results and Discussion}

As shown in Table 9, the results of REM indicate that the model is appropriate as the probability of Chi-Square is significant ( $\mathrm{p}=$ $0.000<0.05)$.

In respect to $\mathrm{H} 1$, the result shows that BSIZ has a negative and significant effect on TQ $(\mathrm{p}=0.013<0.05)$. Therefore, $\mathrm{H} 1$ which proposes a significant negative relationship between board size and corporate market value is accepted. This means that there is a significant negative relationship between board size and corporate market value. It can be argued that the main reason for such result is the large number of directors among Jordanian banks. As shown in Table 3 above, the results of descriptive statistics indicate that the mean value of board size among Jordanian banks is 11.3766, which supports the current negative relationship. According to Lipton and Lorsch (1992), the relevant size of directors was 8 or 9. Similarly, Jensen (1993) suggested that 7 or 8 members are relevant for a firm to accomplish its work. Therefore, keeping the size of members between 7 and 9 is more useful to firms than larger one and contributes significantly and positively toward the value of firm. This gives an important indicator about the efficiency of small board size in supporting the firm value. This result contradicts the suggestion of stewardship theory about the role of large size of board (Rashid \& Islam, 2013) and supports the argument of prior researchers (e.g. Lipton \& Lorsch, 1992; Jensen, 1993) in the efficiency of small board size in working directly to achieve specific goals in firm. Most important, the current negative and significant result is in line with that of Yermack (1996) who also found high mean vale (12.25) for the board size of USA companies. On the other hand, the result contradicts that of Rashid and Islam (2013) who found a positive significant relationship between board size and firm value when the mean value of board size is relatively small (8.05). Similarly, Naseem et al. (2017) findings also revealed a positive and significant relationship between board size and firm value as the mean value of board size in their study is relevant (7.87). Therefore, the notions of agency theory and resource independence theory (e.g. Hillman \& Dalziel, 2003) towards the role of board of directors in improving the value of firms is true only in presence of small number of boards according to the current result. The current negative relationship is also consistent with the findings of Mak and Kusnadi (2005), Haniffa and Hudaib (2006) and Kumar and Singh (2013). Accordingly, it can be argued that the relevant size (i.e. from 7 to 9 members) is more efficient in supporting firm value (Lipton \& Lorsch, 1992; Jensen, 1993; Eisenberg, Sundgren and Wells, 1998).

In respect to $\mathrm{H} 2$, the result shows that BMET has no effect on TQ $(\mathrm{p}=0.068>0.05)$. Therefore, $\mathrm{H} 2$ which proposes a significant and positive relationship between the frequency of board meetings and corporate market value is rejected. This means that there is no relationship between the frequency of board meetings and corporate market value. This insignificant result is consistent with the findings of Naseem et al. (2017) and Bhat et al. (2018) and contradicts that of Ntim and Osei (2011) and Mishra and Kapil (2018) who found a positive and significant relationship between BMET and firm value. This result does not support the agency theory which gives more emphasis to the meetings of board of directors in coordinating the efforts of board to monitor the different actions of management (Jensen, 1993; Ntim \& Osei, 2011). The justification for insignificant result according to Bhat et al. (2018) is that such meetings are costly and take little time which may not affect the value of firm. In addition, Al-Musali and Ismail (2015) justified non-contribution of BMET in the intellectual capital due to inability of directors to access the necessary information that related to strategic agenda of meeting which affects their ability to participate in decision making process. However, Lipton and Lorsch (1992) argued that board meetings need several preparatory and regulatory procedures to be efficient in supporting the monitoring role of members. Most important, it looks that holding meetings may only performed to comply with the requirements of regulations. Furthermore, it looks that the negative relationship between the bank value and board size is reflected also on the feasibility of board meetings. 
In respect to $\mathrm{H} 3$, the result shows that AMET has a significant positive impact on TQ ( $\mathrm{p}=0.004<0.05)$. Accordingly, H3 is accepted. Therefore, it can be concluded that there is a significant positive relationship between the frequency of audit committee meetings and corporate market value. This result supports the agency theory which suggests that audit committee meetings are necessary to control the agency cost (Bhat et al, 2018). In addition, the audit committee size is small and includes only three members in banks. This, however, gives the committee the necessary power to direct their effort towards the benefit of banks during meetings. In the same context, the mean value of audit committee meetings equal to 7.6883 as reported in Table 3 above. This value exceeds the predetermined value in the Instructions of Corporate Governance for Shareholding Listed Companies for the year 2017. Therefore, it can be argued that increasing the meetings of audit committee contributes significantly towards the bank value especially that such members have the necessary practical experiences as determined in the amended instructions of corporate governance for banks No.63/2016. Cormier et al. (2010) noted that contrary to board committee meetings, audit committee meetings have the ability to reduce asymmetry. This however, additional evidence on the different impact for board meetings and audit committee meetings. The significant positive effect of audit committee meetings is consistent with the result of Al-Matari, Al-Swidi and Fadzil (2012).

In respect to the control variable, result shows that there is a positive and strong significant relationship between INVOP and TQ. Therefore, the presence of investment opportunity in this model is very important as it contribute significantly toward the market value of banks in Jordan.

Table 9

Results of Random Effect Model (REM)

\begin{tabular}{llll}
\hline Variable & Coefficient & Z-statistics & P-value \\
\hline $\mathrm{C}$ & 0.8822945 & 113.97 & 0.000 \\
BSIZ & -0.0013095 & -2.49 & 0.013 \\
BMET & -0.0007512 & -1.83 & 0.068 \\
AMET & 0.0005384 & 2.88 & 0.004 \\
INVOP & 0.1348142 & 47.38 & 0.000 \\
\hline $\mathrm{R}^{2}$ within & 0.9616 & & \\
$\mathrm{R}^{2}$ between & 0.9879 & & \\
$\mathrm{R}^{2}$ overall & 0.9846 & & \\
Wald Chi2 & 2313.67 & & \\
Probability & 0.0000 & & \\
\hline
\end{tabular}

\section{Summary and Conclusion}

Based on the secondary data of the Jordanian commercial listed banks for the period from 2013 to 2019, the current study tested empirically the effect of board mechanisms on the firm market value. The dependent variable was measured using Tobin's Q. Three dependent variables were used including board size, board meetings and audit committee meetings. In addition, one controlling variable was used in the current study namely investment opportunity.

The results revealed that the compliance of Jordanian banks with the Amended Instructions of Corporate Governance for Banks No.63/2016 dated 1/9/2016 is high. The results of REM indicated that board size has a significant negative effect on bank value. In addition, the results indicated that frequency of board meetings has no effect on bank value, while the frequency of audit committee meetings has a significant positive effect on bank value. In respect to the control variable, the results revealed a significant and positive relationship between investment opportunity and bank value.

The significant negative effect of board size on firm value is considered new important result as it puts an end to the debate about the nature of the relationship between these two variables depending on the appropriate size of board members. The current study reached an important conclusion in this regard in that the smaller number of board members is more appropriate in supporting firm value as suggested in previous studies (Lipton \& Lorsch, 1992; Jensen, 1993). In addition, the result suggested that the argument of agency theory and resource independence theory towards the effectiveness role of board of directors in firm value should be always linked to an appropriate size of board members. Consequently, the inappropriate size of board of directors in Jordanian banks has also affected the relationship between frequency of board meetings and bank value by making such meetings ineffective to bank value. In addition, this insignificant relationship between board meetings and firm value is related to the willingness of such firms to meet the legal requirements in holding such meetings regardless of their role in enhancing the value of firms. On the other hand, results support the aforementioned argument in that the frequency of audit committee meetings contributes significantly toward of Jordanian banks value as such committee includes small number of directors.

The findings of the current study offer numerous applications to academics and policy makers in banks. First, academics should take into account the results of the initial descriptive statistics of panel data in respect to the number of board members when building the empirical relationship between the board size and the value of firm. Second, the policy-makers in Jordanian banks should reconsider the size of directors by reducing it from that of the currently specified. Third, the policy-makers in Jordanian banks should reconsider the frequency of meetings for the board of directors and audit committee by increasing it from that of the currently specified and by carefully preparing for such meetings (Lipton \& Lorsch, 1992). Fourth, the insignificant effect of board 
meetings on bank value lays a great responsibility on the decision-makers. In particular, this result sends a warning signal to the decision-makers in JSC to activate their monitoring role on such meetings in terms agenda, time and outputs. Fifth, the selection of members of boards and various committees should be subject to predetermined measures that enable decision-makers to identify precisely the value of each member to firm. Finally, despite that banks in Jordan found to be complied with the corporate governance rules, the current study excluded some banks, years, and variables due to lack of governance information about several issues, which limited the study sample and accordingly the number of observations. This also put additional responsibility on the managements of banks to give more attention to the contents of corporate governance report.

The current study opens several avenues for future studies. First, the scarcity of studies that focus on the relationship between audit committee meetings and firm value in particular and the scarcity of studies that focus on the relationship between board of director mechanisms and firm value in banks is important motivation for additional future studies. Second, future studies may add many other variables to the current model to validate their relevancy against different theories. Third, a survey-based study that includes both the qualitative and quantitative approach may be performed to discuss and identify the different issues that related to the meetings of board of directors and its committees. Fourth, future studies may focus on other sectors and time periods. Finally, using panel regression techniques, future studies may focus on the actual relationship between the number of board of directors and firm value according to several time spans.

\section{References}

Abbadi, S. S., Hijazi, Q. F., \& Al-Rahahleh, A. S. (2016). Corporate governance quality and earnings management: Evidence from Jordan. Australasian Accounting, Business and Finance Journal, 10(2), 54-75.

Abu Khalaf, B. K. A., \& Al-Tarawneh, A. (2019). The Impact of Corporate Governance on the Efficiency of Managing Working Capital: The Manufacturing Sector in Jordan. Jordan Journal of Business Administration, 15(2), $201-208$.

Adams, R., \& Mehran, H. (2003). Is corporate governance different for bank holding companies? FRBNY Econ. Policy Rev. 9, $123-142$.

Aebi, V., Sabato, G., \& Schmid, M. (2012). Risk management, corporate governance, and bank performance in the financial crisis. Journal of Banking \& Finance, 36(12), 3213-3226.

Agyemang-Mintah, P., \& Schadewitz, H. (2019). Gender diversity and firm value: evidence from UK financial institutions. International Journal of Accounting \& Information Management, 27 (1), 2-26.

Alabdullah, T. T., Yahya, S., \& Ramayah, T. (2014). Corporate governance mechanisms and Jordanian companies' financial performance. Asian Social Science, 10(22), 247-262.

Al-Amarneh, A., \& Yaseen, H. (2014). Corporate governance and dividend policy in Jordan. International Journal of Economics and Finance, 6(4), 210-219.

Al Attar, M., (2016). Corporate governance and financial statement disclosure quality in Jordanian commercial banks. International journal of Economics and Finance, 8(10), 192-205.

Albitar, K. (2015). Corporate governance and voluntary disclosure: Evidence from Jordan. European Academic Research, 2(10), $13197-13214$

Al Fadli, A., Sands, J., Jones, G., Beattie, C., \& Pensiero, D. (2019). Board Gender Diversity and CSR Reporting: Evidence from Jordan. Australasian Accounting, Business and Finance Journal, 13(3), 29-52.

Al-Khouri, R. (2006). Corporate governance and firms value in emerging markets: The case of Jordan. Journal of Transnational Management, 12(1), 25-49.

Alkurdi, A., Tahat, Y., \& Al-mawali, H. (2017). The effect of governance attributes on corporate dividend payouts policy: Evidence from Jordan. International Journal of Corporate Governance, 8(3-4), 313-334.

Al-Matari, Y. A., Al-Swidi, A. K., \& Fadzil, F. H. B. (2012). Audit committee effectiveness and performance of Saudi Arabia listed companies. Wulfenia Journal, 19(8), 169-188.

Al-Musali, M. A. K. M., \& Ismail, K. N. I. K. (2015). Board diversity and intellectual capital performance. Accounting Research Journal, 28(3), 284-299.

Al-Nimer, M. (2019). Effect of Corporate Governance Rules on Voluntary Disclosure in Jordanian Corporations Listed with the Amman Stock Exchange (ASE):(An Empirical Study). Studies in Business and Economics, 14(1), 154-168.

Al-Rahahleh, A. S. (2017). Corporate governance quality, board gender diversity and corporate dividend policy: Evidence from Jordan. Australasian Accounting, Business and Finance Journal, 11(2), 86-104.

Antenucci, R. (2019). The Weakening Relationship between Corporate Governance and Firm Performance. Association for University Regional Campuses of Ohio, 25, 1-23.

Asante-Darko, D., Bonsu, B. A., Famiyeh, S., Kwarteng, A., \& Goka, Y. (2018). Governance structures, cash holdings and firm value on the Ghana stock exchange. Corporate Governance: The International Journal of Business in Society, 18 (4), $671-$ 685.

Azzoz, A, A., \& Khamees, B. A. (2016). The Impact of Corporate Governance Characteristics on Earnings Quality and Earnings Management: Evidence from Jordan. Jordan Journal of Business Administration, 12(1). 187-207. 
Bawaneh, S. S. (2020). Impact of Corporate Governance on Financial Institutions? Performance: A Board Composition Case. Asian Economic and Financial Review, 10(1), 54-63.

Berthelot, S., Francoeur, C., \& Labelle, R. (2012). Corporate governance mechanisms, accounting results and stock valuation in Canada. International Journal of Managerial Finance, 8(4), 332-343.

Bhat, K. U., Chen, Y., Jebran, K., \& Bhutto, N. A. (2018). Corporate governance and firm value: A comparative analysis of state and non-state owned companies in the context of Pakistan. Corporate Governance. The International Journal of Business in Society, 18(6), 1196-1206.

Bista, N. B., Bartaula, N. R., Shrestha, O., Gnawali, P., Lamichhane, P., \& Parajuli, P. (2019). Impact of Corporate Governance on Dividend Policy of Nepalese Enterprises. In Business Governance and Society (pp. 377-397). Palgrave Macmillan, Cham.

Blundell, R., Bond, S., Devereux, M., \& Schiantarelli, F. (1992). Investment and Tobin's Q: Evidence from company panel data. Journal of Econometrics, 51(1-2), 233-257.

Bushman, R. M. (2014). Thoughts on financial accounting and the banking industry. Journal of Accounting and Economics, $58(2-$ 3), 384-395.

CBJ. (2016a). Amended Instructions of Corporate Governance for Banks No. (63/2016) dated 1/9/2016. Retrieved May 6, 2020 from: https://www.cbj.gov.jo/Pages/viewpage.aspx?pageID=246

CBJ. (2016b). Amended Instructions of Corporate Governance for Islamic (Sharia Compliant) Banks No. (64/ 2016) Dated 25/9/2016.Retrieved May 6, 2020 from: http://www.cbj.gov.jo/Pages/viewpage.aspx?pageID=246

Cormier, D., Ledoux, M. J., Magnan, M., \& Aerts, W. (2010). Corporate governance and information asymmetry between managers and investors. Corporate Governance: The International Journal of Business in Society, 10(5), 574-589.

Crespí, R., García-Cestona, M. A., \& Salas, V. (2004). Governance mechanisms in Spanish banks. Does ownership matter?. Journal of Banking \& Finance, 28(10), 2311-2330.

Daradkah, D. A., \& Ajlouni, M. M. (2013). The Effect of Corporate Governance on Bank's Dividend Policy: Evidence from Jordanll. Australian Journal of Business and Management Research, 3(1), 30-39.

Davis, J. H., Schoorman, F. D., \& Donaldson, L. (1997). Toward a stewardship theory of management. Academy of Management Review, 22(1), 20-47.

de Andres, P., Romero-Merino, M. E., Santamaría, M., \& Vallelado, E. (2012). Board determinants in banking industry. An international perspective. Managerial and Decision Economics, 33(3), 147-158.

de Andres, p. \& Vallelado, E. ( 2008). Corporate Governance in Banking: The role of board of Directors. Journal of Banking \& Finance, 32, 2570-2580.

Del Brio, E. B., Maia-Ramires, E., \& Perote, J. (2006). Corporate governance mechanisms and their impact on firm value. Corporate Ownership and Control, 4(1), 25-36.

Dewasiri, N. J., Koralalage, W. B. Y., Azeez, A. A., Jayarathne, P. G. S. A., Kuruppuarachchi, D., \& Weerasinghe, V. A. (2019). Determinants of dividend policy: evidence from an emerging and developing market. Managerial Finance, 45 (3), 413-429.

Eberhart, R. (2012). Corporate governance systems and firm value: empirical evidence from Japan's natural experiment. Journal of Asia Business Studies, 6(2), 176-196.

Eisenberg, T., Sundgren, S., \& Wells, M. T. (1998). Larger board size and decreasing firm value in small firms. Journal of Financial Economics, 48(1), 35-54.

Elmagrhi, M. H., Ntim, C. G., Crossley, R. M., Malagila, J. K., Fosu, S., \& Vu, T. V. (2017). Corporate governance and dividend pay-out policy in UK listed SMEs. International Journal of Accounting \& Information Management,25 (4), 459-483.

Erkens, D. H., Hung, M., \& Matos, P. (2012). Corporate governance in the 2007-2008 financial crisis: Evidence from financial institutions worldwide. Journal of Corporate Finance, 18(2), 389-411.

Fama, E. F. (1980). Agency problems and the theory of the firm. Journal of Political Economy, 88(2), 288-307.

Fama, E. F., \& Jensen, M. C. (1983). Separation of ownership and control. The journal of law and Economics, 26(2), 301-325.

Farhan, A., Obaid, S. N., \& Azlan, H. (2017). Corporate governance effect on firms' performance-evidence from the UAE. Journal of Economic and Administrative Sciences,33(1), 66-80.

Gregory, H. J., \& Simms, M. E. (1999). Corporate governance: what it is and why it matters. 9th International Anti-Corruption Conference, Kuala Lumpur. 10-15 October 1999, Durban, South Africa.

Gujarati, D, N \& Porter, D, C. (2009). Basic Econometrics. $5^{\text {th }}$ Edition McGraw-Hill/ Irwin. New York.

Hamdan, A. M., Sarea, A. M., \& Reyad, S. M. R. (2013). The impact of audit committee characteristics on the performance: Evidence from Jordan. International Management Review, 9(1), 32-42.

Haniffa, R., \& Hudaib, M. (2006). Corporate governance structure and performance of Malaysian listed companies. Journal of Business Finance \& Accounting, 33(7-8), 1034-1062.

Hill, C. W., \& Jones, T. M. (1992). Stakeholder-agency theory. Journal of management studies, 29(2), 131-154.

Hillman, A. J., \& Dalziel, T. (2003). Boards of directors and firm performance: Integrating agency and resource dependence perspectives. Academy of Management review, 28(3), 383-396.

Hillman, A. J., Withers, M. C., \& Collins, B. J. (2009). Resource dependence theory: A review. Journal of management, 35(6), 1404-1427. 
Ibrahim, M. Y., Ahmad, A. C., \& Khan, M. A. (2017). Does Corporate Governance Mechanism Improve Shareholder Value? A Panel Analysis of Malaysian Listed Companies. Global Business \& Management Research, 9(1), 15-27.

Jensen, M. C., \& Meckling, W. H. (1976). Theory of the firm: Managerial behavior, agency costs, and ownership structure. Journal of Financial Economics, 3, 305-360.

Jensen, M. C. (1993). The modern industrial revolution, exit, and the failure of internal control systems. The Journal of Finance, 48(3), 831-880.

Jiraporn, P., Kim, J. C., \& Kim, Y. S. (2011). Dividend payouts and corporate governance quality: An empirical investigation. Financial Review, 46(2), 251-279.

JSC. (2017). Instructions of Corporate Governance for Shareholding Listed Companies for the year 2017. Available online at: https://jsc.gov.jo/Links2/en/instructions

Kong, Y., Famba, T., Chituku-Dzimiro, G., Sun, H., \& Kurauone, O. (2020). Corporate Governance Mechanisms, Ownership and Firm Value: Evidence from Listed Chinese Firms. International Journal of Financial Studies, 8(2), 1-26.

Kumar, N., \& Singh, J. P. (2013). Effect of board size and promoter ownership on firm value: some empirical findings from India. Corporate Governance: The international journal of business in society, 13 (1), 88-98.

Kusi, B. A., Gyeke-Dako, A., Agbloyor, E. K., \& Darku, A. B. (2018). Does corporate governance structures promote shareholders or stakeholders value maximization? Evidence from African banks. Corporate Governance: The International Journal of Business in Society, 18(2), 270-288.

Lan, L. L., \& Heracleous, L. (2010). Rethinking agency theory: The view from law. Academy of Management Review, 35(2), 294314.

Lipton, M., \& Lorsch, J. W. (1992). A modest proposal for improved corporate governance. The business lawyer, 48(1), 59-77.

Mak, Y. T., \& Kusnadi, Y. (2005). Size really matters: Further evidence on the negative relationship between board size and firm value. Pacific-Basin Finance Journal, 13(3), 301-318.

Malik, M. F., \& Shah, S. M. A. (2013). Value relevance of firm specific corporate governance and macroeconomic variables: evidence from Karachi stock exchange. Pakistan Journal of Commerce and Social Sciences (PJCSS), 7(2), $276-297$.

Mazzotta, R., \& Veltri, S. (2014). The relationship between corporate governance and the cost of equity capital. Evidence from the Italian stock exchange. Journal of Management \& Governance, 18(2), 419-448.

Mishra, R., \& Kapil, S. (2017). Effect of ownership structure and board structure on firm value: evidence from India. Corporate Governance: The International Journal of Business in Society, 17(4), 700-726.

Mishra, R. K., \& Kapil, S. (2018). Effect of Board Characteristics on Firm Value: Evidence from India. South Asian Journal of Business Studies, 7(1), 41-72.

Naseem, M. A., Xiaoming, S., Riaz, S., \& Rehman, R. U. (2017). Board attributes and financial performance: The evidence from an emerging economy. The Journal of Developing Areas, 51(3), 281-297.

Ntim, C. G., \& Osei, K. A. (2011). The impact of corporate board meetings on corporate performance in South Africa. African Review of Economics and Finance, 2(2), 83-103.

Pahi, D. \& Yadav, I.S. (2019). Does corporate governance affect dividend policy in India? Firm-level evidence from new indices. Managerial Finance, 45 (9), 1219-1238.

Perfect, S. B., \& Wiles, K. W. (1994). Alternative constructions of Tobin's q: An empirical comparison. Journal of Empirical Finance, 1(3-4), 313-341.

Rashid, K., \& Islam, S. M. (2013). Corporate governance, complementarities and the value of a firm in an emerging market: the effect of market imperfections. Corporate Governance: The International Journal of Business in Society,13 (1), $70-87$.

Schäuble, J. (2019). The impact of external and internal corporate governance mechanisms on agency costs. Corporate Governance: The International Journal of Business in Society,19(1), 1-22.

Siddiqui, S. S. (2015). The association between corporate governance and firm performance-a meta-analysis. International Journal of Accounting and Information Management, 23(3), 218-237.

Sidhu, M. K., \& Kaur, P. (2019). Effect of corporate governance on stock market liquidity: empirical evidence from Indian companies. DECISION, 46(3), 197-218.

Van Puyvelde, S., Caers, R., Du Bois, C., \& Jegers, M. (2012). The governance of nonprofit organizations: Integrating agency theory with stakeholder and stewardship theories. Nonprofit and Voluntary Sector Quarterly, 41(3), $431-451$.

Yermack, D. (1996). Higher market valuation of companies with a small board of directors. Journal of Financial Economics, 40(2), 185-211.

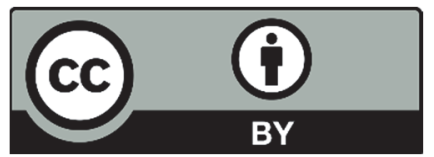

(C) 2021 by the authors; licensee Growing Science, Canada. This is an open access article distributed under the terms and conditions of the Creative Commons Attribution (CC-BY) license (http://creativecommons.org/licenses/by/4.0/). 